\title{
Eksplorasi Pengunjung Taman Merdeka Kota Metro dalam Pengidentifikasian Fungsi Sosial di Ruang Terbuka Publik
}

\author{
I Wayan Suherman ${ }^{1}$, Haris Murwadi ${ }^{2 *}$, \\ ${ }^{1}$ Mahasiswa Magister Teknik, Pascasarjana, Universitas Bandar Lampung \\ ${ }^{2}$ Prodi Arsitektur, Fakultas Teknik, Universitas Bandar Lampung \\ *Penulis Korespondensi: murwadi@ubl.ac.id
}

\begin{abstract}
Abstrak:
Keberadaan taman kota sebagai ruang terbuka hijau di kawasan perkotaan dapat menjadi salah satu sarana dalam membentuk interaksi sosial masyarakat perkotaan. Pemanfaatan taman kota umumnya dilakukan masyarakat dalam ragam alasan, ragam latar belakang, dan ragam waktunya. Penelitian ini bertujuan untuk mengidentifikasi fungsi Taman Merdeka bagi masyarakat di Kota Metro. Metode kualitatif (grounded theory) digunakan sebagai eksplorasi pendahuluan dalam pengidentifikasi fungsi taman. Pengumpulan data dilakukan secara terbuka melalui kuesioner luring terhadap responden yang mengunjungi Taman Merdeka Kota Metro. Content Analysis dilakukan untuk menemukan kata kunci yang berkaitan dengan ativitas sosial masyarakat. Temuan penelitian ini menunjukkan bahwa alasan masyarakat dalam pemanfaatan taman yaitu karena tujuan aktivitas, suasanan, dan kenyamanan. Aktivitas dominan yang dilakukan masyarakat meliputi aktivitas liburan (refreshing), nongkrong, dan istirahat. Sedangkan, alasan suasana dan kenyamanan yang dominan meliputi alasan keindahan (asri) dan nyaman.
\end{abstract}

Kata Kunci: identifikasi; fungsi sosial; Taman Merdeka; Metro

\section{Latar Belakang}

Penyediaan Ruang Publik yang merupakan salah satu bagian dari Ruang Terbuka Hijau (RTH) kota saat ini masih menjadi masalah bagi beberapa kota di Indonesia khususnya kota-kota dengan kepadatan penduduk yang tinggi karena setiap kota sarankan menyediakan Ruang Terbuka Hijau (RTH) minimal 30\% dari luas kota, hal ini berdasarkan pasal 29 ayat (2) UU No 26 tahun 2007 tentang Penataan Ruang, setiap kota harus menyediakan Ruang Terbuka Hijau (RTH) minimal 30\% dari luas kota. Hal tersebut terkait dengan kota yang merupakan sebuah sistem jaringan kehidupan manusia yang ditandai dengan kepadatan penduduk yang tinggi dan diwarnai dengan strata sosial ekonomis yang heterogen serta coraknya yang materialistis. Namun banyak ruang publik yang dirancang dengan baik mengalami kemunduran dan penelantaran, karena layanan dan aktivitas di mana kualitas berkelanjutan ruang-ruang tersebut telah mengalami kendala dan tekanan yang sama untuk perubahan seperti layanan publik pada umumnya (Carmona, 2014).

Ruang Publik berupa Ruang Terbuka Hijau kota adalah bagian dari ruang-ruang terbuka (open spaces) suatu wilayah perkotaan yang diisi oleh tumbuhan, tanaman, dan vegetasi guna mendukung manfaat langsung atau tidak langsung yang dihasilkan oleh RTH dalam kota tersebut yaitu keamanan, kenyamanan, kesejahteraan, dan keindahan wilayah perkotaan tersebut (Departemen Pekerjaan Umum, 2008: 3). Perencanaan Ruang Terbuka Hijau (RTH) jangka panjang diperlukan peraturan perundang-undangan tetapi tidak bertentangan dengan kepentingan bisnis dan preferensi konsumen jangka pendek dari kelas menengah modern yang kuat (Werner, 2014).

Taman Kota merupakan Ruang Terbuka Hijau yang memiliki fungsi untuk keindahan dan interaksi sosial. Fungsi taman kota, selain merupakan elemen estetika kota, juga berfungsi sebagai elemen ekologi kota. Sebagai ekologi kota, taman kota berfungsi sebagai penjaga dan pengatur iklim mikro. Selain itu, taman kota merupakan sarana umum yang ditata serta dibentuk untuk dapat dimanfaatkan oleh seluruh masyarakat kota sebagai sarana sosial. Taman memberikan manfaat dengan menangkap air hujan, memperlambat limpasannya, dan mengurangi volume air yang masuk ke drainase (Harnik et al, 2017).

Taman kota merupakan salah satu jenis ruang terbuka hijau publik yang biasanya dijadikan tempat untuk menghabiskan waktu libur atau sekedar waktu luang di tengah rutinitas. Fungsi taman kota, selain merupakan elemen estetika ruang kota, juga berfungsi sebagai elemen ekologi kota. Sebagai elemen ekologi kota, taman kota berfungsi sebagai penjaga dan pengatur iklim mikro. Menurut sejarahnya Taman Kota dibangun dengan lebih memperhatikan masalah sosial dibandingkan keberlanjutan ekologi (Cranz and Boland, 2004). Selain itu, taman kota merupakan sarana umum yang ditata serta dibentuk untuk dapat dimanfaatkan oleh seluruh masyarakat kota sebagai sarana sosial atau ruang publik.

Taman kota yang berfungsi sebagai ruang publik tentu akan menjadikan lokasi ini ramai dikunjungi banyak orang. Mereka datang melakukan aktivitas yang berbeda-beda, misal ada yang sekedar membaca buku sambil duduk di bawah pohon, jogging, dan mungkin ada yang datang ke taman kota dalam misi untuk berdagang. Ruang publik 
sebagai bagian dari ruang kota tidak dapat dipisahkan keberadaannya dari suatu kota. Ruang publik memiliki arti penting untuk wilayah atau kawasan perkotaan, sebab peranan utama ruang publik adalah menyelaraskan pola kehidupan masyarakat suatu kota. Taman kota sebagai ruang publik ibarat suatu wadah di mana di dalamnya terjadi interaksi sosial (Kustianingrum, 2013).

Masyarakat kota yang memiliki aktivitas, mulai dari pagi hingga sore bahkan dari awal pekan hingga akhir pekan telah menunggu untuk ditunaikan. Melakukan aktivitas yang sama setiap harinya tentu akan menimbulkan suatu kejenuhan. Pengguna taman lebih cenderung mengunjungi taman yang dipelihara dengan baik secara konsisten dimana fasilitasnya aman untuk digunakan.

Masalah lingkungan yang ada di perkotaan pada negara-negara berkembang sangatlah kompleks, diantara banyak masalah lingkungan perkotaan di negara berkembang, berkurangnya ruang terbuka publik secara kualitas dan kuantitas berdampak pada masalah kualitas hidup. Dimana faktor kesehatan adalah faktor utama yang mempengaruhi kualitas hidup seseorang. Taman kota adalah salah satu ruang terbuka publik yang sangat penting keberadaannya. Untuk meningkatkan kualitas lingkungan dan untuk meningkatkan indeks kebahagiaan warga, perlu dibangun ruang terbuka publik yang salah satunya berupa Taman Kota.

Beberapa fungsi sosial dari ruang terbuka hijau sebagai ruang publik diantaranya yaitu sebagai tempat melakukan aktivitas bersama dan komunikasi sosial, tempat peralihan dan menunggu, tempat bermain, olahraga, dan rekreasi, sebagai penghubung antara tempat satu dengan tempat lainnya, pembatas diantara massa bangunan, sebagai tempat penelitian dan pendidikan, sebagai sarana olah raga dan rekreasi, membantu menciptakan kebersihan, kesehatan dan keserasian (Jatmiko, 2015).

Terkait dengan keberadaan RTH di daerah perkotaan tidak terlepas dari beberapa permasalahan yang sering muncul diantaranya yaitu inkonsistensi kebijakan dan strategi penataan ruang, sering terjadi alih fungsi dari RTH, lemahnya kelembagaan, pemeliharaan tidak konsisten dan tidak rutin, sering dianggap tempat sampah, sarang vektor penyakit, pemahaman kurang tentang pentingnya penghijauan dikawasan perkotaan sehingga peran serta masyarakat tidak optimal, lemahnya koordinasi antar instansi, terjadinya tumpang tindih kewenangan/ kesenjangan dalam pengelolaan RTH dan sering terjadi konflik kepentingan ditingkat masyarakat (Dirjen Cipta Karya Departemen Pekerjaan Umum, 2018). Ruang terbuka hijau perkotaan merupakan sumber daya yang berharga untuk aktivitas fisik penduduk perkotaan dan memiliki potensi untuk mengurangi penyakit kronis dan meningkatkan kesehatan (Wang et al., 2019).

Kota Metro merupakan salah satu kota di Provinsi Lampung. Statusnya sebagai wilayah perkotaan membuat kota ini mengalami pembangunan di berbagai lini. Kota Metro juga tengah berusaha untuk menyediakan fasilitasfasilitas sosial yang ditujukan untuk masyarakatnya. Kota Metro sendiri mengalami perkembangan yang luar biasa. Adapun beberapa taman sebagai ruang terbuka hijau yang ada di Kota Metro diantaranya yaitu sebagai berikut:

Tabel 1. Daftar Ruang Terbuka Hijau (RTH) di Kota Metro

\begin{tabular}{lllc} 
No. & \multicolumn{1}{c}{ Nama RTH } & \multicolumn{1}{c}{ Lokasi } & Luas $\left.\mathbf{( m}^{\mathbf{2}}\right)$ \\
\hline $\mathbf{1}$ & Taman Perbatasan Kota & Ganjar Agung-Metro Barat & 30 \\
$\mathbf{2}$ & Taman Gajah & Ganjar Agung-Metro Barat & 1100 \\
$\mathbf{3}$ & Taman Univ.Muhamadiyah & Ganjar Agung-Metro Barat & 900 \\
$\mathbf{4}$ & Taman Simpang 3 Makam Pahlawan & Ganjar Agung-Metro Barat & 300 \\
$\mathbf{5}$ & Taman Prestasi Kencana & Ganjar Agung-Metro Barat & 1500 \\
$\mathbf{6}$ & Taman Samping Dinas Pertanian & Metro & 700 \\
$\mathbf{7}$ & Taman Gedung Sesat & Ganjar Agung-Metro & 15 \\
$\mathbf{8}$ & Taman Merdeka & Metro Pusat & 24400 \\
$\mathbf{9}$ & Taman Pojok Bunderan Tugu Pena & Metro Pusat & 75 \\
$\mathbf{1 0}$ & Taman RSU IPDAM & Metro Pusat & 400 \\
$\mathbf{1 1}$ & Taman Terminal 16C & Metro Barat & 400 \\
$\mathbf{1 2}$ & Taman Pojok Pos Polisi Kota & Metro Pusat & 150 \\
$\mathbf{1 3}$ & Taman Median Depan Kantor Pemda & Metro Pusat & 200 \\
$\mathbf{1 4}$ & Taman Samping Masjid Taqea & Metro Pusat & 15 \\
$\mathbf{1 5}$ & Taman Tugu Pena & Metro Pusat & 20 \\
$\mathbf{1 6}$ & Taman Perempatan RSU Ahmad Yani & Metro Pusat & 20 \\
$\mathbf{1 7}$ & Taman Segitiga Kampus & Metro Timur & 400 \\
$\mathbf{1 8}$ & Taman Bola Tejosari & Metro Timur & 15 \\
$\mathbf{1 9}$ & Taman Bundera Karangrejo & Metro Utara & 10 \\
$\mathbf{2 0}$ & Taman Bunderan Banjar Sari & Metro Utara & \\
\hline
\end{tabular}

Sumber: Dinas Tata Kota dan Pertamanan Kota Metro, 2020 
Berdasarkan tabel di atas, taman Merdeka yang terletak di Metro Pusat dengan luas $24.400 \mathrm{~m}^{2}$ merupakan taman kota terluas yang ada di Kota Metro. Mengacu pada Peraturan Menteri Pekerjaan Umum Nomor 5 Tahun 2008 tentang Pedoman Penyediaan dan Pemanfaatan Ruang Terbuka Hijau di Kawasan Perkotaan, proporsi penyediaan RTH pada wilayah perkotaan adalah sebesar minimal $30 \%$ dari luas wilayah perkotaan tersebut yang terdiri dari $20 \%$ RTH publik dan 10\% RTH privat, sehingga RTH publik yang seharusnya disediakan oleh pemerintah Kota Metro adalah sebesar 20\% dari luas wilayahnya.

Ruang terbuka hijau dianggap infrastruktur sosial dan lingkungan utama untuk keberlanjutan kota. Oleh karena itu, perencanaan yang baik ketika ruang terbatas atau direncanakan untuk wilayah perkotaan baru sangat penting. Perencanaan ruang terbuka hijau umumnya didasarkan pada kebijakan dan pedoman lokal dan jarang diinformasikan oleh bukti empiris. Selain itu, sangat sedikit penelitian yang telah dilakukan dilakukan pada keragaman nilai yang diberikan masyarakat pada ruang terbuka hijau (Ives et al., 2014).

Sejalan dengan Kota Metro yang berkembang dengan pesat, Taman Merdeka pun terus mengalami proses perkembangan sampai saat ini dengan banyaknya orang yang datang dan melakukan aktivitas yang berbeda-beda di dalamnya. Taman Merdeka merupakan ruang publik yang sengaja disediakan oleh pemerintah yang ditujukan untuk kepentingan masyarakat. Pemerintah telah menyediakan lokasi berupa ruang publik dan lokasi ini akan bisa disebut sebagai ruang publik jika digunakan oleh masyarakat untuk melakukan berbagai macam aktivitas. Namun kenyataannya saat ini kuantitas dan kualitas ruang terbuka publik terutama Ruang Terbuka Hijau (RTH) mengalami penurunan yang sangat signifikan dan mengakibatkan penurunan kualitas lingkungan hidup perkotaan dan interaksi sosial

RTH selain berfungsi sebagai kawasan lindung juga berfungsi sosial sebagai open public space untuk tempat berinteraksi sosial dalam masyarakat seperti tempat rekreasi, sarana olahraga dan atau area bermain. RTH ini harus memiliki aksesibilitas yang baik untuk semua orang, termasuk aksesibilitas bagi penyandang disabilitas.

Penelitian sebelumnya mengenai Taman Merdeka masih cenderung umum mengenai fungsi taman sebagai ruang public yang fungsi ekonomi, fungsi wahana interaksi, fungsi lingkungan, fungsi pendidikan, fungsi rekreasi, fungsi transit, dan fungsi kesehatan (Etiningsih, 2016) melalui pendekatan fenomenologinya serta fungsi-fungsi tambahan lainnya seperti budaya fungsi estetika, fungsi ekologis, serta fungsi rekreasi (Andrahan dkk, 2012) melalui pendekatan desktiptif. Berdasarkan penjabaran dalam latar belakang dan penelitian sebelumnya, maka penelitian ini bertujuan untuk mengidentifikasi fungsi Taman Merdeka bagi masyarakat Kota Metro melalui pendekatan grounded theory.

Penelitian ini penting dilakukan sebagai sarana konfirmasi penelitian sebelumnya melalui pendekatan yang berbeda serta dalam perspektif berbeda (perencanaan wilayah kota). Kontribusi Penelitian diharapkan dapat memberikan gambaran secara komprehensif tentang fungsi sosial dari taman kota sebagai ruang publik di kawasan perkotaan sehingga dapat menambah wawasan untuk perencanaan pembangunan wilayah perkotaan. Selain itu, penelitian ini diharapkan dapat menjadi masukan bagi pemerintah Kota Metro yang berkaitan dengan perencanaan dan pembangunan daerah lainnya dalam hal ini tentang fungsi sosial dari taman kota sebagai ruang publik.

\section{Fungsi Sosial Taman Kota sebagai Ruang Publik}

Menurut Kohn (2004) ruang publik adalah ruang yang dapat diakses oleh siapapun dimiliki oleh pemerintahan, dan bekerja secara intersubjektif, dimana dapat berinteraksi satu sama lain disana. Ruang publik adalah ruang untuk politik, agama, perdagangan, olahraga atau ruang untuk hidup berdampingan secara damai dan untuk pertemuan yang tidak bersifat pribadi. Kemudian Hanzl (2013), mengatakan bahwa makna ruang publik membutuhkan pendekatan hubungan antara struktur perkotaan dan budaya penggunaan ruang.

Tibbalds (2001) mengemukakan bahwa ruang publik adalah semua tempat untuk masyarakat yang memiliki akses fisik dan visual, seperti jalan, alun-alun dan taman. Sejalan dengan Tibbalds (2001), Lang (2017) menyebutkan bahwa ruang publik merupakan tempat-tempat di mana semua orang dapat mengakses, meskipun terkadang akses tersebut dapat dikendalikan. Ruang publik terdiri atas dua, yaitu ruang outdoor dan ruang indoor. Jalan, alun-alun, dan taman termasuk ke dalam ruang outdoor. Kemudian, perpustakaan dan pusat perbelanjaan merupakan contoh dari ruang indoor.

Carr (1993) mengatakan bahwa ruang publik adalah panggung berlangsungnya drama kehidupan masyarakat, sebab menurut Tibbalds (2001) ruang publik menggambarkan kondisi masyarakat, budaya masyarakat, dan wacana sehari-hari. Ruang publik menekankan pada akses yang terbuka dan keberagaman kegiatan. Akses terbuka artinya siapa saja boleh memasuki ruang ini dan keberagaman kegiatan yaitu aktivitas yang dilakukan oleh orang-orang yang berada di ruang publik adalah berbeda-beda. Akibat dari akses yang terbuka maka banyak orang yang datang sehingga akan terjadi interaksi sosial.

Berdasarkan pemaparan di atas dapat kita simpulkan bahwa ruang publik adalah tempat di mana kita berinteraksi dan berbagi dengan orang lain atau orang yang tidak kita kenal. Akses ruang publik adalah terbuka yaitu setiap orang memiliki hak untuk memasukinya tanpa harus membayar biaya masuk terlebih dahulu. Ruang publik merupakan ruang milik bersama yang digunakan untuk kepentingan bersama. 
Menurut Darmawan (2005), secara umum terdapat beberapa fungsi ruang publik, yaitu sebagai pusat interaksi masyarakat, sebagai ruang terbuka, sebagai tempat usaha bagi pedagang kaki lima, serta sebagai paru-paru kota. Ruang Terbuka Hijau (RTH) merupakan bagian dari ruang terbuka. Berdasarkan Peraturan Menteri Pekerjaan Umum Nomor 5 Tahun 2008 tentang Pedoman Penyediaan dan Pemanfaatan RTH di Kawasan Perkotaan, ruang terbuka adalah ruang-ruang dalam kota atau wilayah yang lebih luas baik dalam bentuk area/kawasan maupun dalam bentuk area memanjang/jalur dimana dalam penggunaannya lebih bersifat terbuka yang pada dasarnya tanpa bangunan.

Ruang Terbuka Hijau (RTH) sangat penting untuk menyediakan ekosistem yang baik untuk mengurangi tingkat stres sosial dari komunitas yang tinggal di daerah perkotaan yang padat penduduk. Anak-anak sebagai bagian dari komunitas perkotaan, seringkali paling terpengaruh oleh kurangnya ruang terbuka hijau. Kota harus menyediakan setidaknya 30\% dari luas kota yang terutama berfungsi sebagai ruang terbuka hijau, pembentukan proporsi $30 \%$ oleh pemerintah merupakan patokan standar untuk memastikan keseimbangan ekosistem kota, baik diantara keseimbangan sistem hidrologi, iklim mikro, dan sistem ekologi.

Menurut Kamus Bahasa Indonesia, taman adalah kebun yang ditanami dengan bunga-bunga (tempat bersenangsenang) atau tempat yang menyenangkan. dapat diartikan sebagai tanaman yang ditanam dan ditata sedemikian rupa, baik sebagian maupun semuanya hasil rekayasa manusia untuk mendapatkan komposisi tertentu yang indah. Menurut Iswara (2017), taman kota adalah ruang terbuka hijau yang mempunyai fungsi utama untuk keindahan dan interaksi sosial. Taman Kota menurut Peraturan Menteri Pekerjaan Umum Nomor 5 Tahun 2008 adalah lahan terbuka yang berfungsi sosial dan estetika sebagai sarana kegiatan rekreatif, edukasi atau kegiatan lain pada tingkat kota.

Berdasarkan pemaparan di atas maka dapat disimpulkan bahwa Taman Kota adalah lahan terbuka yang ditata sedemikian rupa atau hasil rekayasa manusia sehingga memberikan rasa nyaman dan aman yang berfungsi sosial dan estetika sebagai sarana rekreasi, edukasi dan kegiatan lainnya di tingkat kota yang dikelola oleh pemerintah kota. Secara singkat, Gehl (1989) membedakan aktivitas luar ruang menjadi 3 kategori antara lain aktivitas kebutuhan, aktivitas pilihan dan aktivitas sosial. Berkegiatan di taman merupakan aktivitas pilihan. Pola kegiatan di lapangan terdiri dari bermain, mengasuh anak, olahraga, menunggu, berdagang, bertanding atau lomba, berdoa, dan untuk kegiatan hari besar keagamaan. Penghuni menengah bawah memiliki kebutuhan akan ruang terbuka yang lebih besar (Winandari, 2018). Beberapa penelitian juga menunjukkan bahwa taman yang menarik bagi publik lebih banyak digunakan untuk tujuan olahraga. Taman yang memiliki karakteristik lingkungan yang menarik di dalam dan di sekitar taman adalah motivator yang kuat untuk aktivitas fisik.

\subsection{Taman Kota sebagai Bagian Ruang Terbuka Hijau}

Taman Kota merupakan salah satu Ruang Terbuka Hijau (RTH) yang berbentuk taman yang dikembangkan di wilayah perkotaan. Terdapat bebarapa jenis RTH taman yang ada di wilayah perkotaan, yaitu Taman RT, Taman RW, Taman Kelurahan, Taman Kecamatan dan Taman Kota. Taman Kota bisa diklasifikasikan berdasarkan tipologi RTH. Berdasarkan fisiknya, Taman Kota termasuk dalam RTH non alami sebab Taman Kota sengaja dirancang sedemikian rupa dalam perencanaan suatu perkotaan. Sedangkan contoh RTH alami seperti Taman Nasional yang masih memiliki habitat liar alami.

Fungsi sosial budaya bisa dilihat bahwa Taman Kota menggambarkan budaya lokal yang bisa juga digunakan sebagai tempat rekreasi. Selanjutnya fungsi estetika, yaitu Taman Kota menjadikan wajah suatu kota menjadi lebih indah. Kemudian fungsi ekonomi yaitu kawasan Taman Kota tak jarang dijadikan tempat untuk berdagang oleh para pelaku informal karena banyaknya orang yang datang atau berkunjung di Taman Kota.

Struktur RTH yang berpola ekologis merupakan RTH yang berbasis bentang alam seperti kawasan lindung, perbukitan, sempadan sungai, sempadan danau, pesisir dan sebagainya. Sedangkan RTH yang berpola planologis dapat berupa ruang-ruang yang mengikuti pola struktur kota, seperti RTH Perumahan, RTH Kelurahan, RTH Kecamatan, RTH Kota maupun taman-taman regional/nasional. Jadi, Taman Kota termasuk ke dalam struktur RTH yang berpola planologis.

Kemudian berdasarkan kepemilikannya, Taman Kota termasuk dalam RTH publik. RTH publik adalah Ruang Terbuka Hijau yang dimiliki dan dikelola oleh pemerintah daerah kota/kabupaten yang digunakan untuk kepentingan masyarakat secara umum.

\subsection{Fungsi Sosial Taman Kota}

Karena meningkatnya kebijakan perencanaan urbanisasi dan densifikasi, orang cenderung kurang hidup dengan lingkungan area hijau. Lingkungan estetis yang menarik dapat meningkatkan kesejahteraan dengan meningkatkan kepuasan, keterikatan, dan rasa tanggung jawab pribadi. Pada gilirannya, stres, perasaan kemarahan, agresi dan frustrasi bisa juga berkurang. Orang yang hidup dengan tekanan kerja, kebisingan perkotaan, dan stres lainnya didorong untuk sering mencari bantuan melalui tempat rekreasi outdoor seperti kawasan padang gurun dan taman 
kota (publik). Area hijau diasumsikan merangsang penduduk perkotaan untuk memilih aktivitas fisik yang sehat (mis. berjalan, bersepeda, dll) dan memilih kegiatan sehat ini sebagai moda transportasi. Orang yang menghabiskan lebih banyak waktu di daerah lingkungan hijau cenderung mempertahankan perilaku sehat mereka. Selain itu, ruang hijau yang menarik adalah lingkungan yang bisa menjadi titik fokus untuk beberapa interaksi sosial informal (Khotdee, Singhirunnusorn and Sahachaisaeree, 2012).

Peran utama ruang terbuka publik adalah mempromosikan interaksi sosial melalui kegiatan sosial. Ruang terbuka publik dapat membuka atau mengecualikan peluang untuk interaksi sosial. Situasi ini menuntut untuk dapat diakses dan ruang inklusif yang dibentuk oleh prinsip-prinsip berikut: (1) Menghindari tebal hambatan seperti dinding atau penghalang yang menghalangi jarak pandang antara manusia; (2) mendorong jalur berjalan dan bersepeda daripada jalan-jalan mobil, dan (3) mengintegrasikan beragam kegiatan dan variasi orang berfungsi bersama (Moulay, Ujang and Said, 2017).

Berdasarkan Permen PU No. 05/PRT/M/2008 dinyatakan bahwa, Taman Kota adalah lahan terbuka yang berfungsi sosial dan estetika sebagai sarana kegiatan rekreasi, edukasi, atau kegiatan lain pada tingkat Kota. Bagian dari ruang terbuka suatu kawasan perkotaan yang dirancang, disediakan dengan diisi oleh tumbuhan dan tanaman yang dapat menciptakan kondisi kota yang indah, sejuk, nyaman dan sejahtera untuk mengakomodasi fungsi sosial yang berkaitan erat dengan aktivitas pengguna seperti kegiatan rekreasi, kegiatan olahraga, bermain, berinteraksi dengan tujuan untuk menunjukan sebuah kota yang berkualitas baik dan ideal.

\section{Metode Penelitian}

Penelitian ini dilakukan dengan menggunakan metode kualitatif (grounded theory) dengan metode pengumpulan dan analisis data secara kualitatif dan kuantitatif. Pengumpulan data kualitatif dilakukan melalui kuesioner terbuka secara daring. Metode pengumpulan data dilakukan melalui convenience sampling. Responden yang berpartisipasi merupakan pengunjung Taman Merdeka Kota Metro yang berasal dari Kota Metro dan sekitarnya dengan latar belakang, usia, pendidikan, gender, pekerjaan. Sedangkan, metode analisis data yang dilakukan adalah content analysis. Content analysis dilakukan dalam dua (2) tahap yaitu open coding dan analisis distribusi (Rezkia, 2020). Open coding dilakukan melalui ekstraksi kata kunci terkait jawaban dari responden. Sedangkan analisis distribusi dilakukan untuk mengetahui jumlah kata kunci yang terekstrak.

\section{Hasil dan Diskusi}

Penelitian ini menemukan bahwan alasan berkunjung respoden ke Taman Merdeka (Gambar 1) meliputi alasan aktivitas, suasana, dan kenyamanan. Aktivitas yang dilakukan oleh responden meliputi aktivitas liburan (refreshing) (46\%), nongkrong (21\%), istirahat (13\%), ngobrol (11\%), seru-seruan (3\%), belajar (3\%), dan santai (3\%). Hal ini berarti bahwa responden membutuhkan taman sebagai salah satu tempat mengisi hari libur sebagai sarana refreshing. Selain itu, nongkrong dan istirahat merupakan aktivitas dominan yang dilakukan responden lainnya yang menjadi alasan responden. Sehingga, taman memerlukan fasilitas tempat duduk sebagai tempat aktivitas mereka. Alasan berkunjung berikutnya adalah alasan suasana yang dimiliki Taman Merdeka yaitu indah/asri (54\%), bersih (23\%), rapi $(15 \%)$, dan tertib (8\%). Hal ini berarti bahwa responden cenderung menyukai taman yang rindang (banyak pohon besar) sebagai peneduh aktivitas mereka. Selain itu, bersih, rapih, dan tertib merupakan suasana penunjang yang menjadi alasan mereka untuk beraktivitas. Faktor lainnya yang menjadi alasan responden adalah factor kenyamanan taman yang meliputi kondisi nyaman dan sejuk yang terdapat pad ataman.

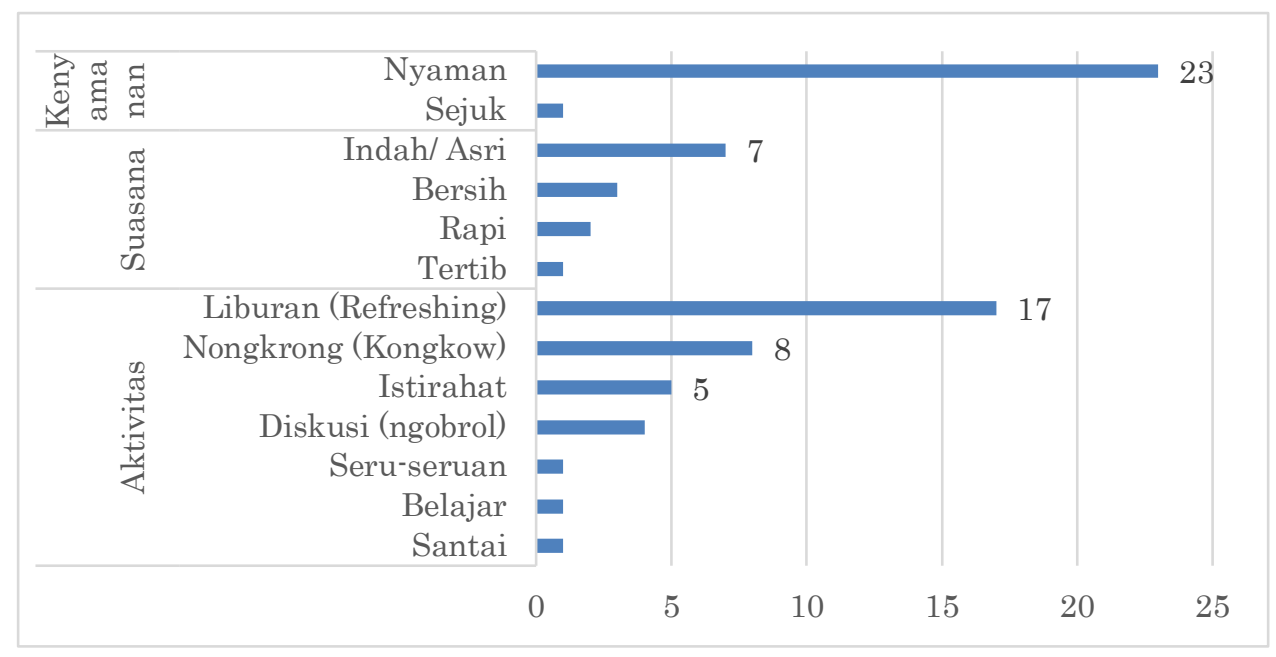

Gambar 1. Distribusi alasan berkunjung responden 
Gambar 2 menunjukkan bahwa rekan berkunjung yang paling dominan adalah teman dan keluarga. Selanjutnya, alasan berkunjung bersama pasangan menjadi urutan berikutnya sebagai rekan berkunjung. Hal ini berarti bahwa fungsi social taman bagi masyarakat yang berkunjung sangat dominan. Kondisi ini menunjukkan bahwa responden yang paling banyak berkunjung merupakan responden yang paling banyak mengajak rekan berkunjungnya. Sehinga, keberadaan taman sebagai fungsi sosial sangat dibutuhkan masyrakat setempat.

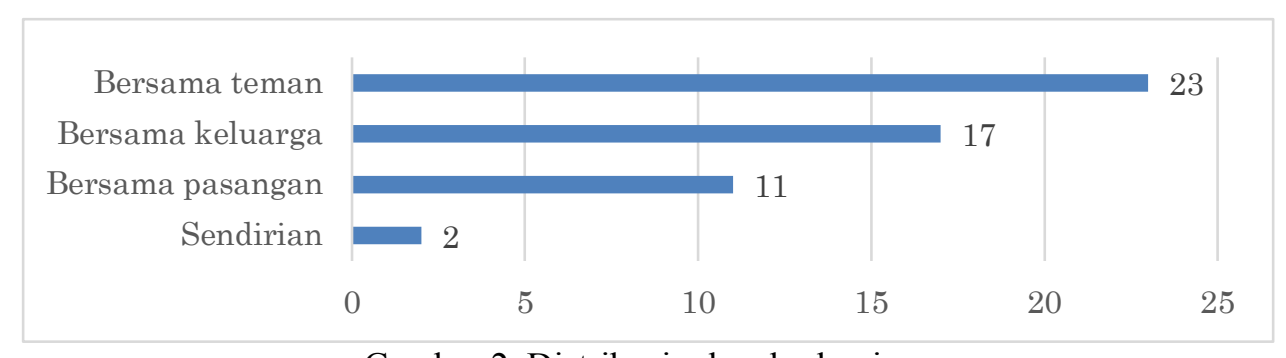

Gambar 2. Distribusi rekan berkunjung

Gambar 3 menunjukkan aktivitas responden saat berkunjung ke Taman Merdeka. Aktivitas dominan yang mereka lakukan adalah santai, duduk, foto, dan mengobrol. Keseluruh aktivitas ini merupakan aktivitas social masyarakat yang cenderung dilakukan secara berkelompok. Hal ini dapat juga disebutkan bahwa kombinasi aktivitas santai dan duduk merupakan kombinasi yang setara dan umum dilakukan. Selanjutnya, aktivitas foto dan mengobrol merupakan aktivitas setara lainnya yang cenderung dilakukan pada era saat ini.

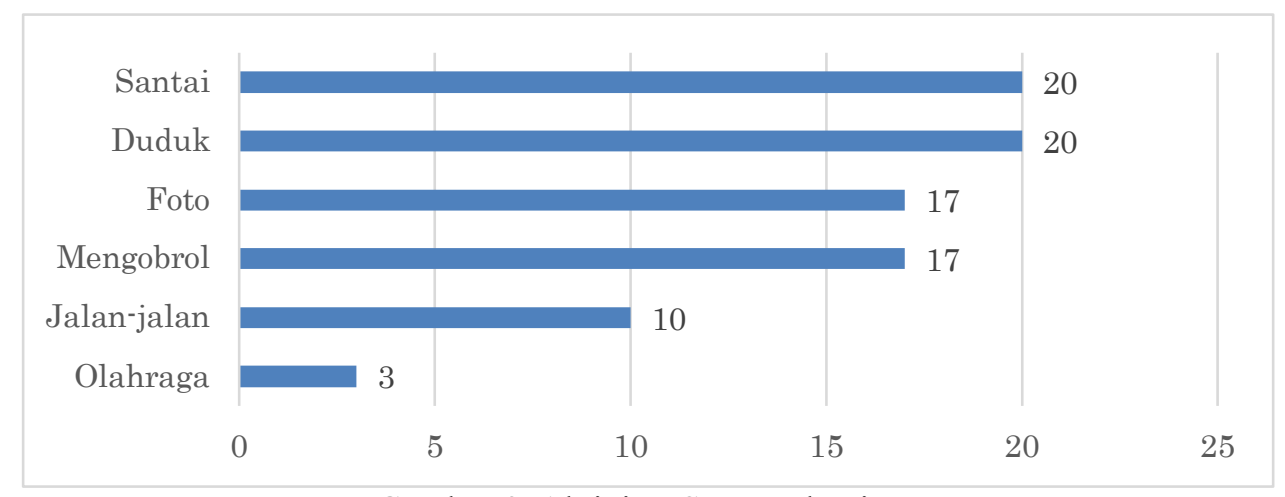

Gambar 3. Aktivitas Saat Berkunjung

Gambar 4 menunjukkan waktu berkunjung dengan frekuensi yang paling sering adalah pada siang hari antara pukul 10.00 sampai 14.00. Kondisi pada jam tersebut merupakan kondisi dengan cuaca yang panas dan terik sehingga suasana yang asri dengan pohon yang rindang sangat berarti pada sebuah taman (lihat gambar 1). Keberadaan gazebo-gazebo juga tentu sangat dibutuhkan dalam memfasilitasi aktivitas pengunjung taman di siang hari. Sedangkan, situasi lainnya cenderung pada kondisi yang tidak terlalu panas.

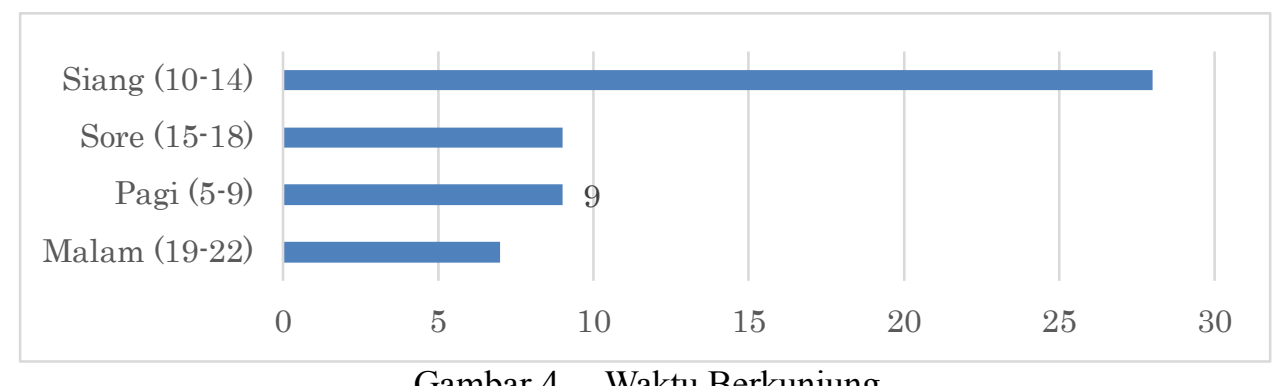

Gambar 4. Waktu Berkunjung

Gambar 5 menunjukkan hari biasa berkunjung responden ke taman yang paling dominan yaitu Hari Minggu. Hal ini merupakan hal yang lazim orang dalam berkunjung ke taman disela-sela aktivitas belajar di sekolah maupun bekerja. Namun, hari lainnya cenderung masih dipilih oleh responden yang kemungkinan besar waktu berkunjung adalah di waktu sore hari. 


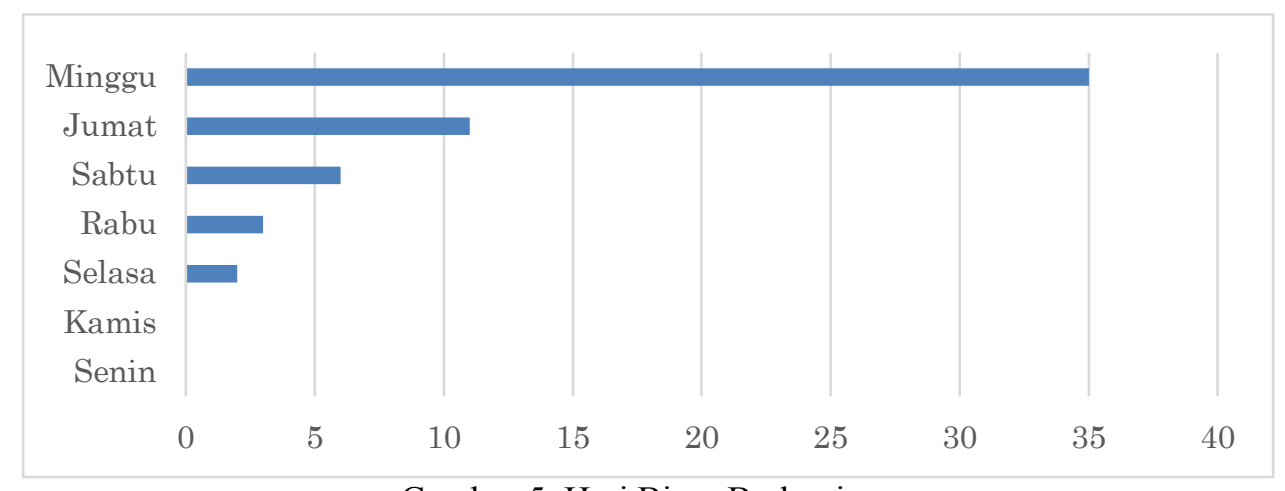

Gambar 5. Hari Biasa Berkunjung

Gambar 6 menunjukkan bahwa dari 50 orang responden, lebih dari 50\% responden berkunjung pada satu pekan terakhir. Sisanya, lebih dari 10 orang terakhir kali berkunjung dua pekan terakhir serta kurang dari 5 orang terakhir kali berkunjung dua bulan terakhir dan satu tahun terakhir. Hal ini berarti bahwa mayoristas pengunjung taman merupakan pengunjung setia yang sering mendatangi taman tersebut.

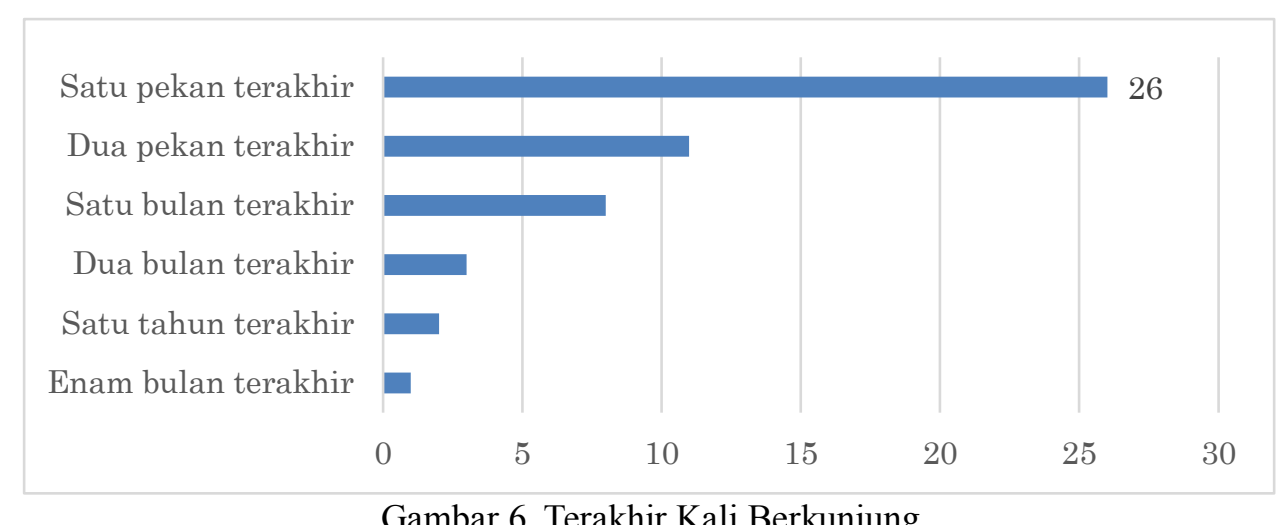

Gambar 7 menunjukkan 50\% responden menyukai area nomor 5, sedangkan sisanya menyukai area nomor 4, nomor 2, nomor 1, serta 5 orang menyukai area nomor 3. Area nomor 5 (bagian tengah taman) menjadi facorit pengunjung disebabkan area tersebut terdapat Tugu Meterm yang merupakan mascot Taman Merdeka. Sehingga, pengunjung banyak menggunakan area ini sebagai lokasi untuk foto-foto.
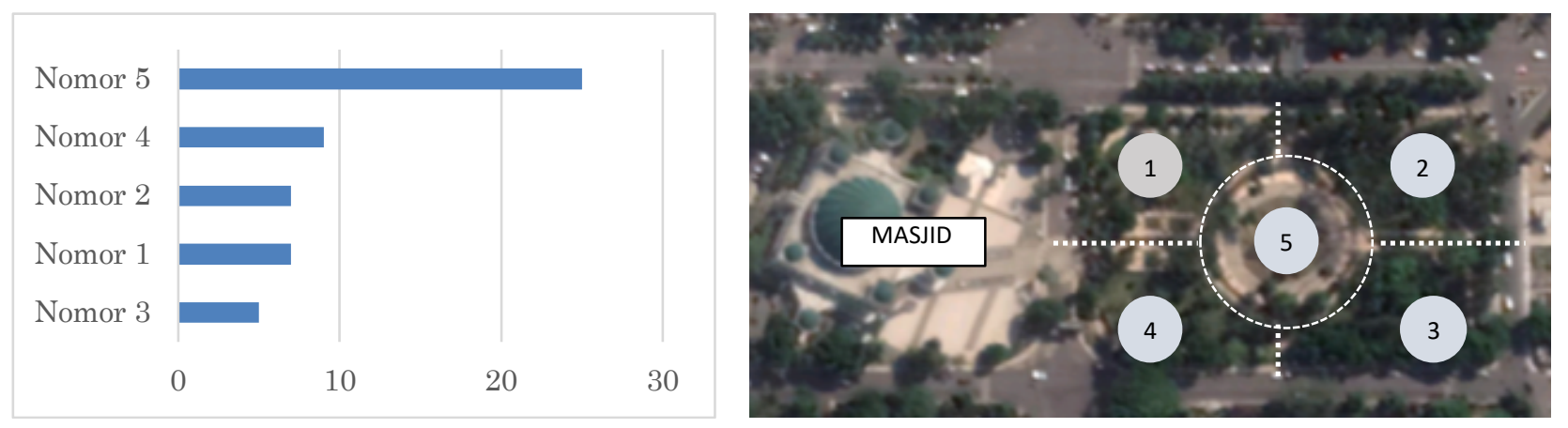

Gambar 7. Area Yang Disukai

Berdasarkan hasil pada gambar 8 berikut ditemukan bahwa dari 50 orang responden, lebih dari 16 responden mengemukakan alasannya pada area favorit sebagai alasan yang bagus dan nyaman, 14 responden dengan alasan sejuk, 8 responden dengan alasan strategis, 6 responden dengan alasan ramai, sedangkan sisanya masing-masing 1 responden yang beralasan bersih dan rapi. Hal ini berarti bahwa area 5 cenderung disukai responden karena bentuk dan kesan yang dihasilkan oleh responden. Sehingga, keberadaan mascot atau sculpture pada sebuah taman diperlukan sebagai daya tarik tersendiri. 


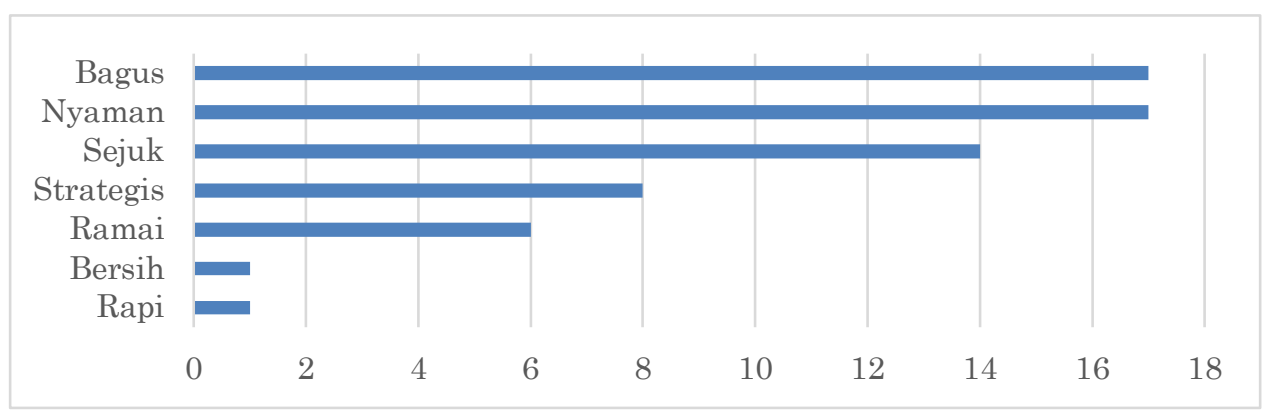

Gambar 8. Alasan Menyukai Area Tersebut

Hasil pada gambar 9 berikut menunjukkan bahwa distribusi frekuensi berkunjung responden cenderung merata. Namun, mayoritas responden menyatakan bahwa mereka cukup sering mendatangi taman, sedangkan sisanya menjawan sangat sering dan jarang. Hal ini berarti bahwa $68 \%$ responden merupakan responden dengan intensitas mendatangi taman yang cenderung menengah ke atas. Gambar 10 menunjukkan bahwa mayoritas pengunjung (84\%) merupakan pengguna motor sedangkan $14 \%$ pengguna mobil sedangkan sisanya (2\%) bersepeda. Hal ini berarti bahwa moda transportasi yang paling praktis saat ke taman adalah dengan menggunakan motor.

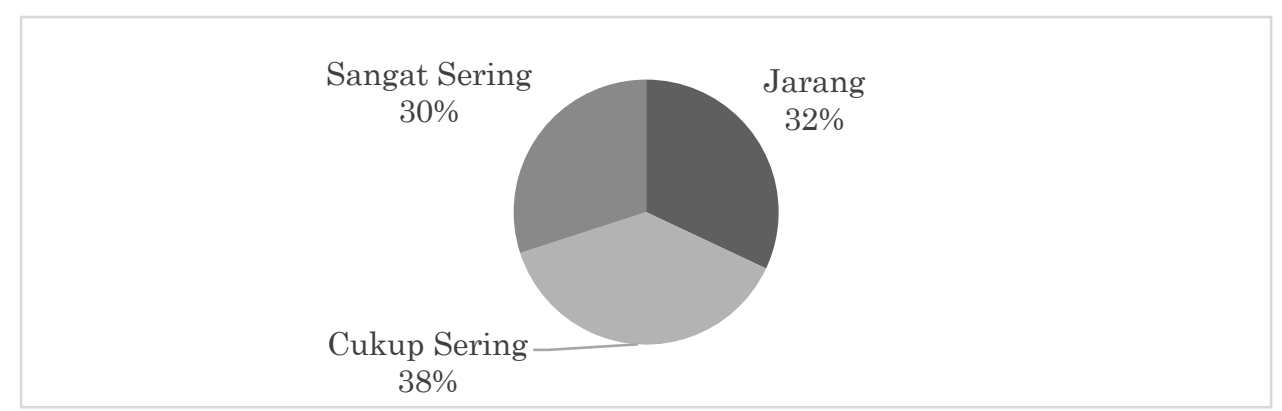

Gambar 9. Frekuensi kunjungan

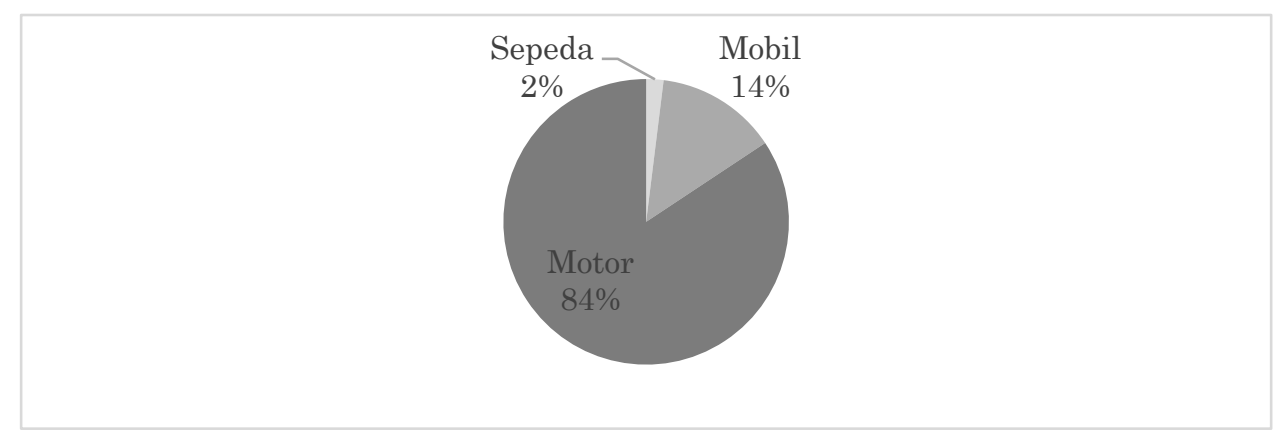

Gambar 10. Cara Mencapai Taman Kota

Berdasarkan hasil gambar 11 berikut diketahui bahwa dari 50 orang responden, lebih dari 30 orang parkir di area taman, lebih dari 15 orang parkir di area masjid Taqwa dan hanya sedikit sekali yang parkir di RSUD Ahmad Yani Metro. Hal ini disebabkan telah disediakannya lokasi parkir khusus untuk sepeda motor pengunjung taman, yang letaknya di sisi taman yang berdekatan dengan RSUD A Yani Metro. Para pengunjung yang parkir di RSUD Ahmad Yani diduga hanya sekedar sambilan saja.

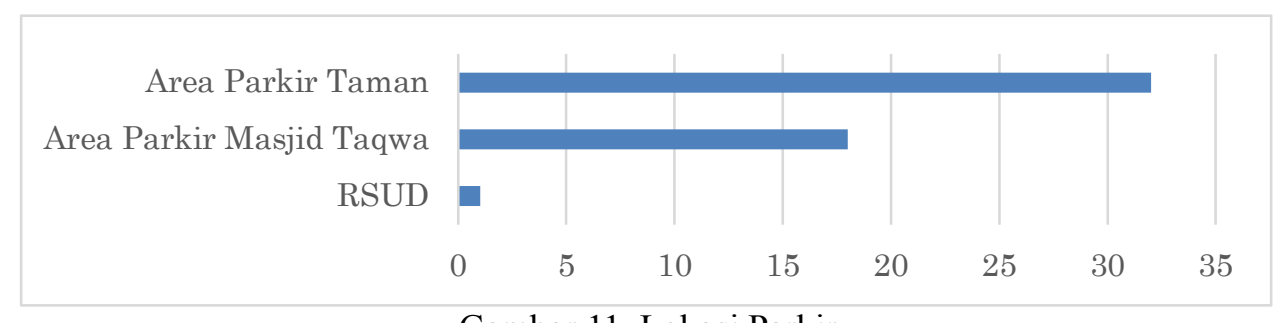

Gambar 11. Lokasi Parkir 
Berdasarkan hasil gambar 12 berikut diketahui bahwa dari 50 orang responden, lebih dari $25 \%$ responden beralasan aman dalam memilih tempat parkir. Alasan responden lainnya seperti dekat dan strategis dan adanya tukang parkir cukup dipilih secara sedang. Sedangkan rapih dan tertib merupakan alasan minor dalam memilih tempat parkir. Hal ini berarti bahwa area parkir di taman merupakan area yang paling dirasa aman oleh pengunjung.

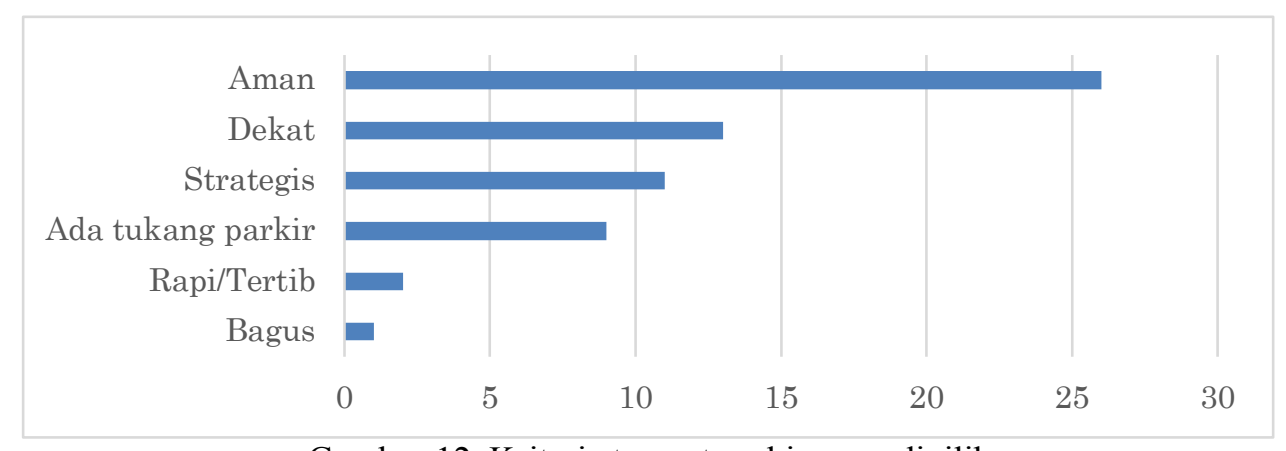

Gambar 12. Kriteria tempat parkir yang dipilih

Sedangkan, persepsi tempat parkir yang nyaman bagi pengunjung adalah tempat parkir yang ada tukang parkir, lokasi tepat (strategis) dan luas (Gambar 13). Hal ini berarti bahwa perasaan aman pengunjung dalam memarkirkan kendaraan sangat dipengaruhi oleh adanya tukang parkir. Sedangkan dekat dan strategis dianggap sebagai lokasi yang tepat dalam memilih parkit. Hal ini berarti bahwa dalam mendesain sebuah taman perlu memperhatikan aspek parkir dan kenyamanannya. Karena, hal ini cukup berpengaruh dalam pemilihan keputusan untuk mendatangi sebuah taman.

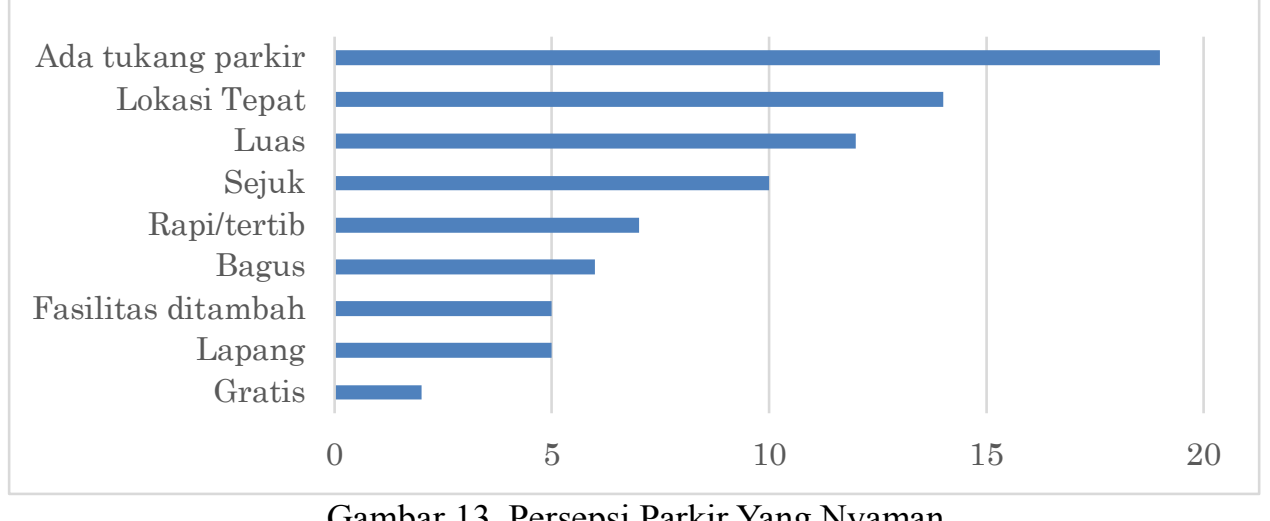

Gambar 13. Persepsi Parkir Yang Nyaman

Berdasarkan hasil tersebut dapat diketahui dari 50 orang responden, kurang dari 20 orang menjawab seharusnya ada tukang parkir, kurang dari 15 orang menjawab lokasi harus tepat, lebih dari 10 orang menjawab harus luas, 10 orang menjawab sejuk, masing-masing lebih dari 5 orang menjawab rapi dan bagus, masing-masing 5 orang menjawab fasilitas ditambah dan lapang, kurang dari 5 orang menjawab gratis. Hal ini disebabkan mayoritas pengunjung yang datang menggunakan sepeda motor sehingga sangat membutuhkan tempat parkir yang aman, dan dekat. Untuk itu tempat parkir yang ada dikelola oleh tukang parkir untuk menjaga keamanan tempat parkir.

Berdasarkan hasil tersebut dapat diketahui dari 50 orang responden, lebih dari 30 orang menyarankan taman harus bersih dan rapi, lebih dari 25 orang menyarankan fasilitas taman harus bagus atau ditambah, masing-masing 5 orang menyarankan lebih edukatif dan ada kantin, kurang dari 5 orang menyarankan taman harus luas. Hal ini disebabkan pengunjung yang datang lebih menyukai suasana taman yang nyaman untuk digunakan sebagai tempat bersantai dan ngobrol bersama teman atau keluarga.

\section{Kesimpulan}

Hasil identifikasi alasan masyarakat berkunjung ke Taman Merdeka Kota Metro ditemukan bahwa pola aktivitas, suasana dan kenyamanan merupakan faktor -faktor yang menjadi pertimbangan dalam mengunjungi taman. Factor aktivitas merupakan factor terkait kegiatan pengunjung sedangkan factor suasana merupakan factor yang diharapkan masyarakat yang terdapat pada taman. Selain itu, factor kenyamanan juga menjadi hal yang harus tepenuhi pula.

Penelitian ini juga menemukan adanya fungsi social yang optimal dengan keberadaan taman tersebut. Hal ini ditunjukkan dengan adanya aktivitas bersama rekan yang dominan yaitu aktivitas bersama teman dan keluarga. 
Aktivitas sosial yang paling menjadi pilihan pengunjung adalah aktivitas santai, duduk, foto, dan ngobrol. Waktu yang paling banyak dikunjungi yaitu pada Hari Minggu di siang hari.

Penelitian ini masih terdapat kelemahan dan perlu dilanjutkan secara kuantitatif. Pendekatan lanjutan secara kuantitaif diharapkan dapat mengonfirmasi hasil penelitian melalui data responden yang lebih banyak. Selain itu, pendekatan kuantitatif dapat melihat hubungan dan pengaruh dari latar belakang dan variable-variabel lainnya.

\section{Daftar Pustaka}

Andrahan, Ova., Yarmaidi., Haryono, Edy.(2012). Fungsi Taman Kota Metro Sebagai Ruang Terbuka Publik Tahu. Draf Artikel.

Carmona, m. (2014) public space: the management dimension.

Carr, s. Et al. (1993) 'public space', in public space. Doi: 10.4324/9781315794808-4.

Cranz, g. And boland, m. (2004) 'defining the sustainable park: a fifth model for urban parks', landscape journal, 23(2), pp. 102-120. Doi: 10.3368/1j.23.2.102.

Darmawan, e. (2005) 'ruang publik dan kualitas ruang kota', proceeding, seminar nasional pesat 2005, pp. $23-24$.

Gehl, j. (1989) life between buildings: using public space, landscape journal. Doi: 10.3368/lj.8.1.54.

Hanzl, m. (2013) 'the meaning of public spaces', green design, materials and manufacturing processes proceedings of the 2 nd international conference on sustainable intelligent manufacturing, sim 2013, (july), pp. 39-44. Doi: 10.1201/b15002-9.

Iswara, r., astuti, w. And putri, r. A. (2017) kesesuaian fungsi taman kota dalam mendukung konsep kota layak huni di surakarta.

Ives, c. D. Et al. (2014) 'planning for green open space in urbanising landscapes', (october), p. 94. Available at: https://www.environment.gov.au/system/files/pages/25570c73-a276-4efb-82f4-16f802320e62/files/planninggreen-open-space-report.pdf.

Jatmiko, b. W. (2015) 'kajian fungsi sosial terhadap taman kota sebagai ruang terbuka hijau di kota semarang', pp. 4-8.

Khotdee, m., singhirunnusorn, w. And sahachaisaeree, n. (2012) 'effects of green open space on social health and behaviour of urban residents: a case study of communities in bangkok', procedia - social and behavioral sciences, 36(june 2011), pp. 449-455. Doi: 10.1016/j.sbspro.2012.03.049.

Kohn, m. (2004) brave new neighborhoods: the privatization of public space, brave new neighborhoods: the privatization of public space. Doi: 10.4324/9780203495117.

Kustianingrum (2013) 'fungsi dan aktifitas taman ganesha sebagai ruang publik di kota bandung', reka karsa, 1(2), pp. 1-14.

Lang, j. (2017) 'urban design: a typology of procedures and products: illustrated with over 50 case studies', urban design: a typology of procedures and products, pp. 1-236. Doi: 10.4324/9781315642406.

Moulay, a., ujang, n. And said, i. (2017) 'legibility of neighborhood parks as a predicator for enhanced social interaction towards social sustainability’, jcit, 61, pp. 58-64. Doi: 10.1016/j.cities.2016.11.007.

Peter harnik, jessica sargent, and j. P. (2017) 'the economic benefits of the public park and recreation system in the city of los angeles, california', the trust for public land.

Rezkia, s. M. (2020) data analisis : 2 jenis metode yang penting untuk kamu tahu dalam analisis data, dqlab. Available at: https://www.dqlab.id/data-analisis-pahami-2-metode-analisis-data.

Tibbalds, f. (2001) making people friendly towns: improving the public environment in towns and cities. London: spon press.

Wang, h. Et al. (2019) 'influence of urban green open space on residents' physical activity in china', bmc public health, 19(1), pp. 1-12. Doi: 10.1186/s12889-019-7416-7.

Werner, c. (2014) 'green open spaces in indonesian cities : schisms between law and practice', pacific geographies, 41(february), pp. 26-31.

Winandari, m. I. R. (2018) 'pemanfaatan dan pengelolaan ruang terbuka di perumahan tangerang', pp. $220-226$.

Etiningsih, Eva. (2016) Fungsi Taman Kota sebagai Ruang Publik (Studi di Taman Merdeka Kota Metro). Skripsi Fakultas Ilmu Sosial dan Ilmu politik, Universitas Lampung. 